\title{
Radio Preaching in Southern Appalachia
}

\author{
Rebecca Dean \\ University of Pittsburgh, Pittsburgh, Pennsylvania, USA
}

\begin{abstract}
Appalachian inspired Pentecostal radio preaching maintains the Protestant legacy of that region first settled through the medium of radio. These sermons are characterized by high levels of affect in delivery, and serve to differentiate "preacher culture" from those denominations that abandoned their original heritage for admittance into middle class status. Thus, preacher culture is an act of both religious and class descent because they are "inspired" by the Holy Spirit (that is, not composed before delivery). Gramscian notions of hegemony are used to interpret how "preacher culture" has maintained itself since the settlement by the northern British and the Scots to Appalachia. The genre of melodrama and "preacher culture" share significant parallels and content, dynamics of presentational styles, and because of these basic parallels, theories of melodrama offer analytical methods for analysis of the content of the inspired sermons and the way of life they elaborate. Gramscian notions of negotiation and consent are used to analyze the maintenance of "preacher culture", which maintains both tradition and cultural specificity that is characteristic of southern Appalachia.
\end{abstract}

Keywords: Preacher culture, southern Appalachian inspired radio preaching, cultural maintenance, cultural specificity

\section{Purpose}

Religious radio broadcasting is central to the maintenance of West Virginia's strong religious culture, especially that of the fundamentalist Holiness/Pentecostal inspired preaching. The state's religious broadcasting features church services and ministry largely from Protestant denominations; but it is inspired preaching, a primary tenet and historical thread that stretches back to the dissenting Protestant legacy of the region's first British settlers, which radio and television religious broadcasting have helped maintain. Inspired preaching presumes that anyone, man or woman, may be chosen by the Holy Spirit to "divine the word" in a variety of ways, preaching being chief among them. Inspired preaching sets inspired doctrine in motion with the preacher as divine channel for an act of philosophical, social and political expression and discourse by, most importantly, traditional working and lower classes in the language of their Scots-Irish forebears. This "preacher culture" maintains the tenets of inspired doctrine and contributes to the articulation and elaboration of cultural specificity of West Virginia, especially in the highlands and coal fields far from urban centers.

\section{History}

Since the eighteenth century, fundamentalist preachers and ministers have primarily communicated with their immediate communities while itinerant preachers travelled the roads and Indian trails to evangelize. The mass medium of radio, followed by television, provided communication across a forbiddingly mountainous

Rebecca Dean, Ph.D., Professor of Communication Studies, Northampton Community College, University of Pittsburgh. 
region where travel could prevent even trips to church.

Fundamentalist denominations, especially Holiness and Pentecostals, relocate practical conflict into sermons characterized by high levels of energy, passion and affect and are explorations of subjective experience. Characteristic of Holiness/Pentecostal preaching are high levels of affect: extreme volume, gasping between long streams of words, weeping, non-differentation between scripture and subjective experience, a background "chorus" of response and support are termed "possession trance" (PT) in anthropology. The denial of middle class decorum in ministry is interpreted as proof of divine inspiration, validates the veracity of the sermon and contributes to and reinforces the oral traditions of West Virginia and the greater South. Inspired worship and preaching offers intense emotional and physical release and is a forum for issues in which the region negotiates emergent and residual elements of culture while helping maintain linguistic, religious and social history and tradition.

\section{Research Population}

\section{Charleston}

The preaching act is a primary mode of elaboration of southern Appalachian culture, its beliefs and practices; the main centers of religious broadcasting West Virginia are in Charleston, Huntington and the Beckley areas. Charleston, the capitol of West Virginia located in the Kanawha Valley, is home to Praise 101, WJYP FM Christian broadcasting. Its format features praise, worship and light gospel music; its sister station on AM is WSCW 1410. Other popular religious stations are Christian Family Radio 89.5 FM and 90.7 AM, as well as WVSR 102.7 FM. Montgomery, near Charleston on the eastern end of the Kanawha Valley, is home to the religious station WZKM, while St. Albans, in the western region of the Valley, was home to locally known minister F.D. Russell. Reverend Russell preached over radio from the 1940's into the late 1960's and his farewell statement at each broadcast has gone down in regional history; "Remember, now; stay prayed up so you can go up!”, a reference to The Rapture when God's chosen people are thought to literally rise up through the air into heaven.

West Virginia’s most famous minister is T.D. Jakes from Smithers, WV. Bishop Jakes began his ministry in Cross Lanes and expanded into television on WCHS, WVAH Television in Charleston. Unable to secure the funding and support for national evangelical television and radio broadcasting within the state, he relocated to Texas where he heads a highly successful church and media ministry. His departure still resonates within the religious broadcasting community of West Virginia and exemplifies the continued tension between the two evangelical broadcast camps: the regionalists whose followings are comprised of their own congregations (or lone preachers, mostly working men and women who feel "the call" to preach) and those with national broadcast goals. This second group regards their regional and rural broadcast brethren as having a "limited vision”. T.D. Jakes is often described as "lost" to parochial West Virginia for the more cosmopolitan, expansive outlook of Texas where he is now nationally broadcast into American and Mexican homes and as well as such venues as women's prisons. Regionalists, on the other hand, are deeply suspect and ambivalent of the potentially corrupting influence of national religious broadcasting: Jim Bakker and Jimmy Swaggart are prime examples of the corrupting influence of mass media's money, power and fame.

\section{Huntington}

Huntington, in the south west part of the state on the Ohio River, is a very important site for religious broadcasting. There are at least 2,500 churches on 60 mile radius of Huntington and more churches in Fifth Ave 
than any other street in the world according to Guinness Book of World Records. Chief among its religious stations is WEMM religious radio, which is celebrating its thirtieth year of commercial free religious broadcasting with the same ownership, format and dial position. Another major religious station is JOY Radio 1420 AM (www.havejoy.com). Religious broadcasting from Kentucky and Ohio are also important to Huntington's radio life: WOKT out of Ashland, Kentucky has a Huntington signal; MEJ out of Proctorville, Ohio features noncommercial easy listening gospel music and preaching; and WOKE out of South Shore, Kentucky features preaching and teaching and bluegrass gospel. Moreover, Huntington is home of the American Radio Museum. The Huntington area's most famous radio and television broadcaster is Pastor Darryl Huffman of New Life Church in Huntington; he is carried on INSP a national religious outlet in North Carolina.

\section{Beckley}

The Beckley area of southeastern West Virginia features longlived religious broadcasting and broadcasters. WCIR/WJLS AM is all religious broadcasting 24 hours a day; its Program Director of fifty plus years is Brother Carlos Lewis, a World War II veteran awarded the Purple Heart for the loss of a leg in defense of his country. His Saturday morning radio show, "Hour of Prayer" is one of the longest running religious radio shows in the United States. In keeping with the democratic ethos of Holiness/Pentecostalism, Brother Carlos organizes the preaching on WJLS according to first come first serve; ministers, preachers and ordinary citizens come into the station and sign up for broadcast slots and are scheduled in that order. Beckley is also home to WWNR AM: talk radio featuring paid religious broadcasting by both white and black ministers. This station's most famous minister is the Reverend Andrew Durgan. His "Sweet Hour of Prayer" has been broadcast for over fifty years and the Reverend himself is in his early nineties; he was the first black funeral director in the state and the first black minister in West Virginia to organize rallies in support of Dr. Martin Luther King, Jr. with the help of fellow black minister Mrs. Helen Dobson. Reverend Durgan's radio show features sermons, testimonials, reading of letter and the minister's own powerful experiences: on a recent show he recounted serving his country in the Second World war yet having to sit in the back of the troop trains. As mentioned earlier, Mrs. Helen Dobson is West Virginia's senior Black woman preacher having more than fifty years of radio ministry to her credit.

Another well known Beckley area radio minister is Sister Loretta Taylor who is a Holiness/Pentecostal pastor of her own house of prayer as well as preacher and is one of very few women to hold both positions in this fundamentalist Christian denomination. Women preachers benefit by radio's absence of the visual element because it is held that the physical expressiveness of inspired preaching could be sexually arousing to watching males. Radio removes the problematic female body from messages of often deep significance; however, women preachers are still not entirely accepted and that ambivalence can contribute to even more affect and power in their preaching. Her family assists in both her ministry and radio preaching; many accompany her, including children and grandchildren, to WJLS on a weekly basis. Bluefield, not far from Beckley, offers WPAR (Positive Alternative Radio) all religious programming which is part of a seven-station religious radio group in West Virginia, Virginia and North Carolina. In the same vicinity if Oakhill, home to WOAY AM all religious programming. WOAY's low frequency makes it ideal for local preaching by ministers of small congregations for local evangelism and community involvement. 
Religious broadcasting in West Virginia remains a central component to the region's mass media and continues to elaborate linguistic, social and religious cultural beliefs.

\section{References}

Armstrong, B. (1989). The Electric Church. New York: Thomas Lenson Publishers.

Colagrosso, C. (2002). Program Director of WJYP, Praise 101. Interview.

Deborah, V. M. (1995). Appalachian Mountain Religion. Chicago: University of Illinois Press.

Dorgan, H. (1993). The Airwaves of Zion. Knoxville: University of Tennessee Press.

Frazer, C. A. (1992). Miners and medicine. Norman, OK: University of Oklahoma Press.

Gaventa, J. (1980). Power and powerlessness. Urbana: University of Illinois Press.

Lawless, E. (1988). Handmaidens of the Lord. Philadelphia: University of Pennsylvania Press. 